\title{
Trachelomonas species as the main component of the euglenophyte community in the Siemianówka Reservoir (Narew River, Poland)
}

\author{
K. Wołowski ${ }^{1 *}$, M. Grabowska² \\ ${ }^{1}$ W. Szafer Institute of Botany, Polish Academy of Sciences, 31-512 Kraków, Lubicz 46, Poland \\ ${ }^{2}$ Department of Hydrobiology, Institute of Biology, University of Białystok, Białystok, Poland
}

As euglenophytes were found to be especially abundant in the Siemianówka Reservoir, Poland, in July 1994, a detailed floristic survey was made. Among the 40 euglenophyta taxa, Trachelomonas was most frequent, with 29 species. The other taxa were Phacus (5), Euglena (5), Lepocinclis (4) and Monomorphina (1). Nine taxa were first recorded for Poland: Trachelomonas curta var. minima, T. intermedia var. papillata, T. neotropica, T. globularis fo. punctata, T. oblonga var. australica, T. planctonica fo. longicollis, fo. ornata, and var. flexicollis, T. silvatica. Details of ultrastructure are illustrated for 29 taxa. T. volvocina var. coranata and var. papilato-punctata are documented with SEM for the first time.

Keywords: Euglenophyta, Trachelomonas, Euglena, Phacus, Monomorphina, Lepocinclis, taxonomy, ultrastructure, algae, eutrophic, reservoir

\section{Introduction}

Euglenophytes are worldwide organisms occurring mainly in freshwater habitats. The growth rate of their biomass is only lower than that of diatoms, green algae, blue-green algae and cryptophytes (Safonova 1987). Their communities are well known in small water bodies rich in organic matter (Skuja 1956, Wołowski 1998, Wołowski \& Hindák 2004, 2005, Paczuska et al. 2002, Bucka \& Wilk-Woźniak 2000). They are very tolerant to pollution, quickly respond to environmental changes of organic pollution level (Wołowski 2002). Several taxa are included in saprobe systems (e.g. Kolkwitz \& Marson 1908, Fjerdingstad 1964, Sladeček \& Sladečkova 1996). In spite of their potential use as indicators of environmental conditions, little is known about euglenophyta communities in large water bodies such as lakes and reservoirs. Most reports provide only general information about the representatives of the group, including only lists of species or genera (Holz et al. 1997, Naselli-Flores 2000). This is probably due to the view that Euglenophyta are not quantitatively important in large water bodies (Safonova 1987). Monitoring of phytoplankton abundance and species composition in Finnish lakes and Spanish reservoirs showed that euglenophytes are largely

* Corresponding author: E-mail : ibwolowski@ib-pan.krakow.pl restricted to eutrophic and hypertrophic conditions (Dasí et al. 1998, Lepistö \& Rosenström 1998).

There have also been some studies reporting data on euglenophyte communities in various types of lake. For instance, Kusel-Feltzman (2002) reported 139 euglenophyta taxa from the shallow, brackish Lake Neusiederl, with only 13 taxa of Trachelomonas. It seems that water salinity limited the occurrence of Trachelomonas species. Yamagishi (1992) reported 165 euglenophyte taxa from dams, lakes and ponds of Taiwan, the loricate taxa consisting of 19 Strombomonas and 58 Trachelomonas. Confortii (1993, 1993a) reported 133 loricate taxa from the shallow Camaleao lake from Brazil, consisting in 90 Trachelomonas and 43 Strombomonas. Conforti and Pérez (2000) reported 54 taxa of euglenophytes from three reservoirs located on the Rio Negro in Uruguay, the 48 loricate taxa, i.e. 26 Strombomonas and 22 Trachelomonas. Similar results were found in a long study (1992-2003) of the phytoplankton of the polyhumic Siemianówka Reservoir, in Poland (Grabowska et al. 2003). The aim of the present paper is to provide more detailed information on two aspects:1) euglenophyte community composition, 2) Trachelomonas taxa occurring abundantly in 1994, with special attention to taxonomic and ultrastructural studies using LM and SEM microscopy. 


\section{Study area}

The Siemianówka Reservoir is located on the upper Narew River in north-eastern Poland (52 $2^{\circ} 55^{\prime} \mathrm{N}, 23$ o50'E) (Fig. 1) near the state border with Byelorussia. It is a shallow reservoir (constructed in 1990) characterized by a high concentration of dissolved humic substances. Morphometric parameters (max area $32.5 \mathrm{~km}^{2}$, max capacity 79.5 million $\mathrm{m}^{3}$, mean depth $2.5 \mathrm{~m}$ ) reflect its lowland character (Górniak \& Jekatierynczuk-Rudczyk 1995a). The highest inflow and water level have occur in spring (max. 1994), fall in summer and autumn, to reach the lowest level in winter. The water residence-time ranges from 4 to 6 months (Górniak \& Jekatierynczuk-Rudczyk 1998).

The catchment is characterized by peat and forest areas. It is free of major sources of pollution (Górniak \& Jekatierynczuk-Rudczyk 1995a). Nevertheless, rapid eutrophication was reported during the first years of the reservoir (Górniak et al. 2000). Since 1992 development of blue-green algal blooms has been a regular phenomenon (Górniak \& Grabowska 1996, Grabowska 1998, 2005, Grabowska et al. 2003). During the blooms the presence of microcystins RR, YR, LR was detected (Tarczyńska \& Zalewski 2000). Grabowska et al. (2003) showed the important role of DOC in addition to nitrogen and phosphorus influencing the taxonomic composition of the phytoplankton.

The dense fish community is mostly due to artificial stocking (Wiśniewolski 2002). Strong grazing pressure by cyprinid species explain the poor development of large zooplankton (Górniak \& Chocian 1999), and decrease in cladoceran body length and biomass (Smakulska \& Górniak 2004). Benthic filter feeders were dominated by Planorbidae and Lymnaedidae (Jurkiewicz-Karnkowska 1999). In 2000, a restoration project was initiated (Górniak et al. 2002).

The water of the reservoir is alkaline (calcium bicarbonate type). Annual and seasonal changes of water quality were described earlier (Górniak \& Jekatierynczuk-Rudczyk 1995b, 1998, Górniak et al. 2002, Grabowska et al. 2003).

\section{Materials and methods}

Surveys of the Siemianówka reservoir (SR) were made monthly from April to October 1994 at three sites (Fig. 1). Water was sampled for analysis from a boat using a Bernatowicz sampler $\left(5 \mathrm{dm}^{3}\right)$ at 0.5 and $2 \mathrm{~m}$. Water samples $\left(300 \mathrm{~cm}^{3}\right)$ for phytoplankton studies

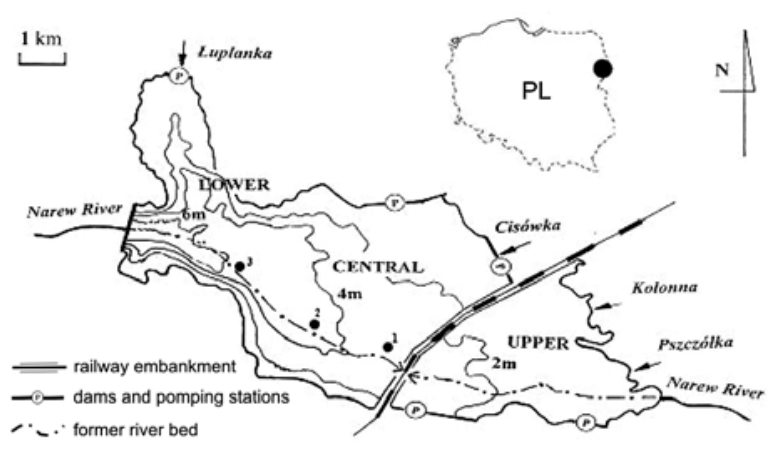

Fig. 1. Map of the Siemianówka reservoir (SR) with bathymetry and distribution of sampling stations; upper, middle, lower - parts of reservoir.

were fixed with Utermöhl's solution. The species were determined using a Nikon ECLIPSE 600 and Olympus BX-50 microscope. Quantitative microscopy analyses were carried out in a Fuchs-Rosenthal chamber. Trachelomonas species were also studied using a Philips XL30 Scanning Electron Microscope. Samples were prepared according to Bozzola \& Russell (1991). Material fixed with Utermöhl's solution was rinsed in distilled water several times to remove buffer salts, after which the samples were dehydrated in a graded ethanol series and small drops of materials were transferred onto the surface of the slides mounted on SEM stubs and air-dried. The samples were coated using platinum-gold sputter coating. Species identification was made according to Deflandre (1926), Tell \& Conforti (1986). The biomass of algae was determined using the method of calculating the volume of cells on the basis of the measurements of the sampled material. Taxa new to the Polish flora are indicated with asterisk $(*)$.

\section{Results}

The main euglenophyte taxon during the study period was Trachelomonas (Figs 4-56) with 29 species. The other euglenophytes were: Euglena (E. viridis), Lepocinclis (L.acus, L. oxyuris, L. spirogyra, L. texta), Phacus (Ph. acuminatus, Ph. curvicauda, Ph. longicauda var longicauda, Ph. pleuronectes, Ph. tortus) and Monomorphina pyrum. The highest Trachelomonas abundance (Fig. 2) and biomass (av. $0.975 \mathrm{mg} \mathrm{dm}^{-}$ ${ }^{3}$ ) (Fig. 3) were found in July. The main components of the 135 phytoplankton taxa at this time were Chlorophyceae $(43 \%)$ and Euglenophyta $(29.6 \%)$. 


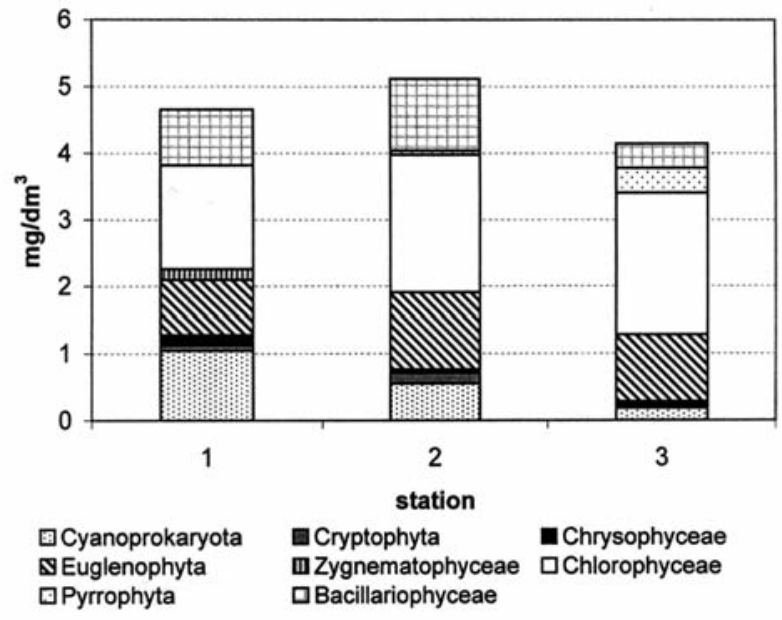

Fig. 2. Average biomass of phytoplankton in SR on 15 July 1994 (mean values from surface layer 0,5 and $2 \mathrm{~m}$ ).

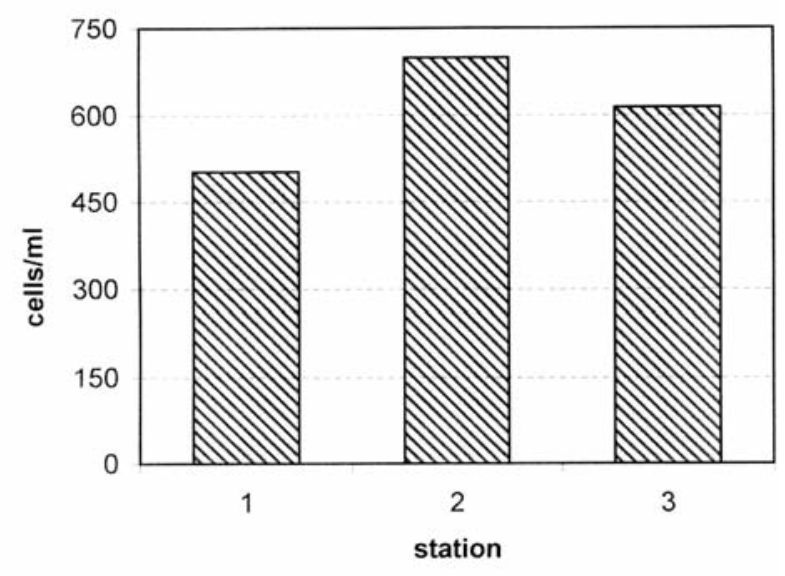

Fig. 3. Average Trachelomonas abundance in SR on 15 July 1994.

\section{List of taxa with taxonomic comments}

\section{Trachelomonas volvocina Ehrenberg}

1883 var. volvocina

Figs 4, 28, 29

Lorica globular, smooth, $10-13.5 \mu \mathrm{m}$ in diameter, apical pore $1.5-2.5 \mu \mathrm{m}$ in diameter; occurred very frequently at sites 1,2 and 3. Cosmopolitan, widespread.

\section{T. volvocina var. punctata}

Playfair 1915

Figs 5, 30, 31

Lorica globular, punctate (1-3 points per $\left.1 \mu \mathrm{m}^{2}\right)$, ca.12.0 $\mu \mathrm{m}$ diameter; apical pore $1.8 \mu \mathrm{m}$ diameter, surrounded by a thickening; occurred singly at sites 1 , 2 and 3. Widespread common. Note: lorica punctuations not well visible in LM.

\section{T. volvocina var. derephora}

Conrad and Van Meel 1952

Fig. 6

Lorica almost globular, smooth, 10-12.5 $\mu$ in diameter; apical pore $1.8 \mu \mathrm{m}$ in diameter, surrounded by $1-$ $1.5 \mu$ high collar; occurred sparsely at sites 1,2 and 3 . Widespread, common.

\section{T. volvocina var. papillato - punctata}

Skvortzov (Popova 1966)

Fig. 7

Lorica globular, thickly punctate (2-4 points per $1 \mu \mathrm{m})$, ca.17.5 $\mu \mathrm{m}$ in diameter, apical pore $2.8 \mu \mathrm{m}$ in diameter surrounded by papillae; occurred sparsely at site 2. Reported rare from Europe (Romania) and Asia (Russia). Note: Papillae at the apical pore are not clearly visible in LM; Fig. 6 showed together with the described variety at right side there are also 2 specimens of $T$. volvocina var. volvocina.

\section{T. volvocina var. coronata \\ Dreżepolski 1925}

Figs 8, 33, 34

Lorica almost globular, punctate (1-2 points per $1 \mu \mathrm{m})$ and covered by small, rare papillae, 20.1-21.5 $\mu \mathrm{m}$ long, $17.5 \mu \mathrm{m}$ wide; apical pore surrounded by well developed collar $2.2 \mu$ high $4.2 \mu$ wide; occurred sparsely at sites 2 and 3 . Reported rare from Europe; first time documented by LM and SEM.

\section{T. volvocinopsis var. volvocinopsis}

Swirenko 1914

Fig. 32, 42

Lorica almost globular, smooth, 14-15.5 $\mu \mathrm{m}$ in diameter, apical pore with annular thickening; occurred very frequently at sites 2 and 3 . Widespread, cosmopolitan.

*T. curta Da Cunha 1914 var. minima

Tell et Zalocar 1985

Figs 9, 36, 37

(=T. lismorensis Playfair 1915 var. inermis Playfair 1915)

Lorica transversely oval, covered by small papillae, 10.0-11.0 $\mu \mathrm{m}$ wide and 9.8-10.5 $\mu \mathrm{m}$ long; apical pore surrounded by an annular thickening; occurred sparsely at sites 1, 2 and 3. Widespread, reported from Argentina (South America), Asia, U. S. A and Europe, not common. Note: specimens are larger than those described by Tell \& Zalocar (1985: $9.5 \mu \mathrm{m}$ wide, $7.5 \mu \mathrm{m}$ long).

\section{T. rugulosa Stein fo. meandrina}

Conrad and Van Meel 1952

Figs 10, 38, 39

Lorica globular, covered with anastomosing, slightly spirally arranged folds, ca.14.5 in diameter; apical pore ca. 2.0 in diameter, surrounded by a ringlike thickening; occurred frequently at site 2 . Widespread, common. 

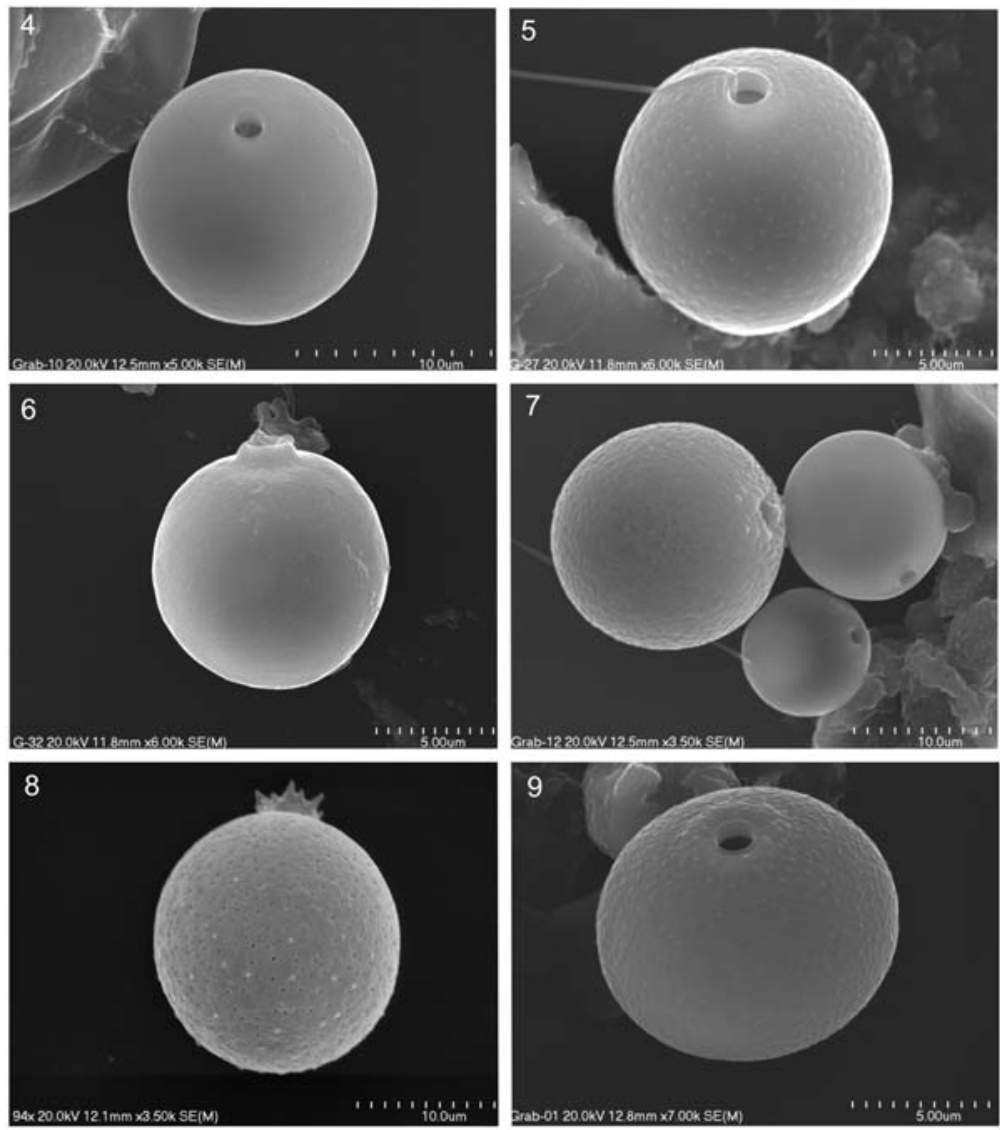

Figs 4-9: 4. Trachelomonas volvocina var. volvocina; 5 . T. volvocina var. punctate; 6. T. volvocina var. derephora; 7. T. volvocina var. papillato-punctata; 8. T. volvocina var. coronata; 9. T. curta var. minima

\section{T. compacta Middelhoek 1948}

Figs. 11, 40, 41

Lorica oblong, scrobiculate, ca. $11.5 \mu \mathrm{m}$ wide and $12.5 \mu \mathrm{m}$ long; apical pore $1.4 \mu$ in diameter; surrounded by thickening. Occurred singly at sites 2 and 3; widespread, common. Note: reported specimens are smaller than those described by Middelhoek (1948).

\section{*T. oblonga Lemmermann 1899 var. australica Playfair 1915}

Figs. 12, 35

Lorica obovoid, slightly narrowed at the posterior end, smooth, 12-5-13.5 $\mu \mathrm{m}$ long 12- $13.0 \mu \mathrm{m}$ wide; apical pore surrounded by short collar $(1.8-1.3 \mu \mathrm{m}$ in diameter); occurred frequently at sites 2 and 3 . Widespread, but not common; reported from Asia, Australia, South America. Note: this taxon is similar in shape to $T$. borodinin which is bigger and to $T$. volvocina var. derephora, which is broadly rounded at the posterior end.

\section{Trachelomonas oblonga Lemmermann 1899} var. oblonga

Figs. 13, 43, 44

Lorica oblong, smooth 10.5-12.6 $\mu \mathrm{m}$ wide, 12.5$13.0 \mu \mathrm{m}$ long; apical pore $1.5 \mu \mathrm{m}$ diameter without collar; occurred very frequently at sites 1,2 and 3 . Widespread, cosmopolitan.

\section{T. intermedia Dangeard 1901 fo. intermedia}

Figs. 14, 45

Lorica ellipsoid to ovoid; punctate (3-4 points per $\left.1 \mu \mathrm{m}^{2}\right)$, 14.5-16.5 $\mu \mathrm{m}$ wide, 16.5-19.5 $\mu \mathrm{m}$ long, apical pore $2.5 \mu \mathrm{m}$ in diameter, without collar, sometimes surrounded by irregularly rimmed thickening; occurred frequently at site 2 . Widespread, cosmopolitan.

\section{*T. intermedia fo. crenulatocollis (Szabados)} Popova 1966

Fig. 16

Lorica broadly ellipsoidal, finely punctate as in typi- 

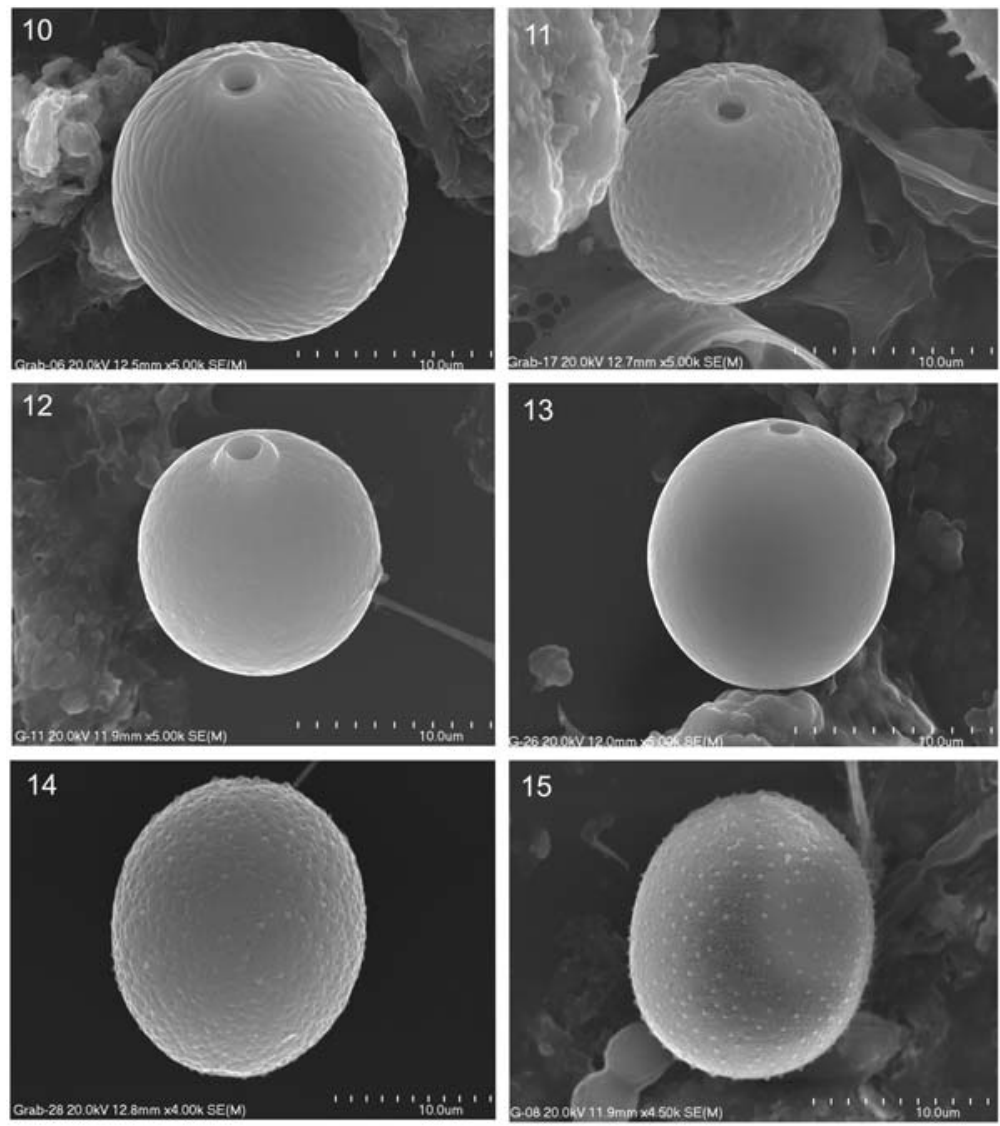

Figs 10-15: 10. T. rugulosa fo. meandrina; 11. T. compacta; 12. T. oblonga var. australica; 13. T. oblonga var. oblonga; 14. T. intermedia fo.intermedia; 15. T. intermedia fo. papillata

cal form, ca.19.0 $\mu \mathrm{m}$ wide and $21.0 \mu \mathrm{m}$ long; apical pore surrounded by a low collar with a crenate rim; occurred sparsely at site 2 . Widespread, common.

\section{T. intermedia fo. papillata (Skuja)}

Popova 1966

Fig. 15

Lorica elliptical, punctate (2-6 points per $1 \mu \mathrm{m})$ and covered by papillae, ca. $14.5 \mu \mathrm{m}$ wide and $16.6 \mu \mathrm{m}$ long; occurred singly at sites 2,3 . Widespread, common. Note: Forma is similar to T. granulosa var. subglobosa Playfair, but papillae are rarely dispersed.

\section{*T. neotropica Balech 1944}

Figs 17, 46

Lorica broadly ellipsoid, punctate (3-4 points per $\left.1 \mu \mathrm{m}^{2}\right)$ and covered by granules (1-2 per $\left.1 \mu \mathrm{m}^{2}\right)$ ca. $13.0 \mu \mathrm{m}$ wide and $15.6 \mu \mathrm{m}$ long; apical pore surrounded by several conical spines; occurred singly at site 2 . Widespread, reported from Argentina (South America), Europe and Asia, but not common.
T.pseudofelix Deflandre 1926

Figs 18,47

Lorica oblong, punctate and covered by irregular granules, $14.5 \mu \mathrm{m}$ wide, $17.5 \mu \mathrm{m}$ long; apical pore surrounded by granules; occurred singly at sites 2,3 . Widespread, not common.

T. hispida (Perty) Stein 1878 emend.

Deflandre 1926 var. hispida

Fig. 48

Lorica elliptical or broadly elliptical; densely punctate (3-6 points per $1 \mu \mathrm{m}^{2}$ ) and covered with spines, 16.5-22.0 $\mu \mathrm{m}$ wide, 20.0-26.0 $\mu \mathrm{m}$ long; occurred very frequently at sites 1 and 2. Cosmopolitan, widespread.

*T. globularis fo. punctata (Skvortzov)

Popova 1966

Fig. 19

Lorica globular, punctate (1-3 points per $\left.1 \mu \mathrm{m}^{2}\right)$ and covered by sharp spines, ca. $21.2 \mu \mathrm{m}$ wide and 24.3 $\mu \mathrm{m}$ long; apical pore surrounded by ring of longer spines; occurred single at site 2 . Widespread, common. 

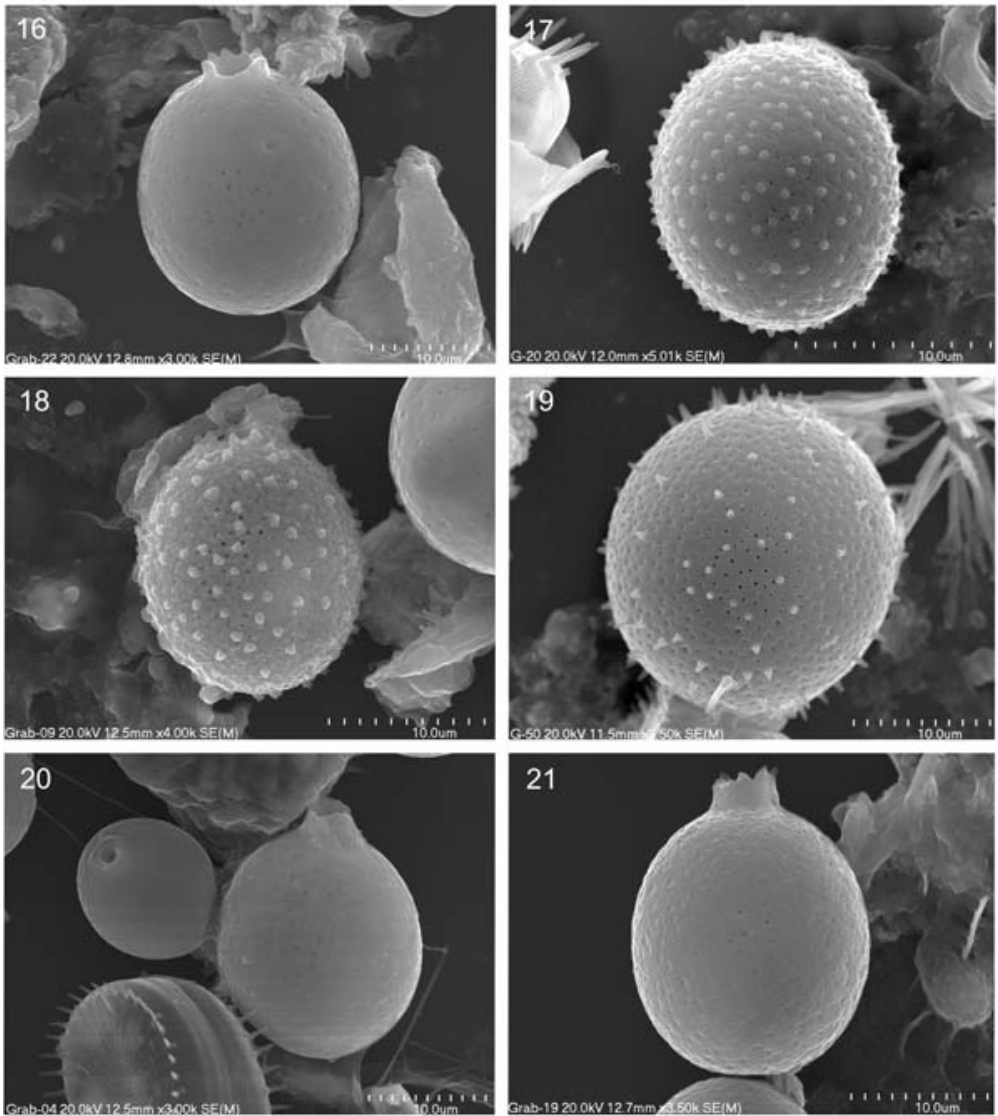

Figs 16-21: 16. T. intermedia fo. crenulatocollis; 17. T. neotropica; 18. T. pseudofelix; 19. T. globularis fo. punctata; 20. T. mangini fo. subpunctata; 21. T. planctonica var. planctonica fo. planctonica

T. mangini Deflandre 1926 fo. subpunctata Safonova 1963

Fig. 20

Lorica oblong, punctuate, ca. $17.3 \mu \mathrm{m}$ wide and 22.3 $\mu \mathrm{m}$ long, apical pore with well developed collar $3 \mu \mathrm{m}$ high; ccurred singly at site 2 . Not common, reported from Europe, Asia and South America. Note: on Fig. 20 lorica attached T. volvocina and partly of Stephanodiscus sp.

\section{*T. planctonica Swirenko 1914 var. planctonica fo. planctonica}

Figs 21, 49

Lorica broadly elliptical, densely punctate (1-2 points per $\left.1 \mu \mathrm{m}^{2}\right), 17.1-18.5 \mu \mathrm{m}$ wide, 20.3- $23.5 \mu \mathrm{m}$ long; apical pore surrounded by irregularly toothed collar, ca. 1.8-3.3 $\mu \mathrm{m}$ high; occurred very frequently at sites 2 and 3. Cosmopolitan, widespread.

\section{T.planctonica var. planctonica fo. longicollis} (Skvortzov) Popova 1966

Fig. 22
Lorica broadly elliptical, punctate, ca. $18.3 \mu \mathrm{m}$ wide and $23.3 \mu \mathrm{m}$ long with well developed straight collar $5 \mu \mathrm{m}$ high with regularly toothed rim; occurred sparsely at site 2 . Widespread. common.

\section{T. planctonica var. planctonica fo. oblonga} (Dreżepolski) Popova 1966

Fig. 23

Lorica oblong, punctate $\left(1-3\right.$ points per $\left.1 \mu \mathrm{m}^{2}\right)$, ca. $17.6 \mu \mathrm{m}$ wide and $26.0 \mu \mathrm{m}$ long, collar straight, irregularly toothed at the rim $4.0 \mu \mathrm{m}$ high; occurred sparsely at site 2. Widespread, common.

*T. planctonica fo. ornata (Skvortzov) Popova 1955 Figs 50-52

Lorica broadly elliptical, covered by spines (3-5 spines per $1 \mu \mathrm{m}^{2}$ ), 18.3-19.0 $\mu \mathrm{m}$ wide, $20-22.5 \mu \mathrm{m}$ long; collar straight, irregularly toothed at the rim 2.0$2.4 \mu \mathrm{m}$ high; occurred frequently at sites 2 and 3 . Widespread, common. 

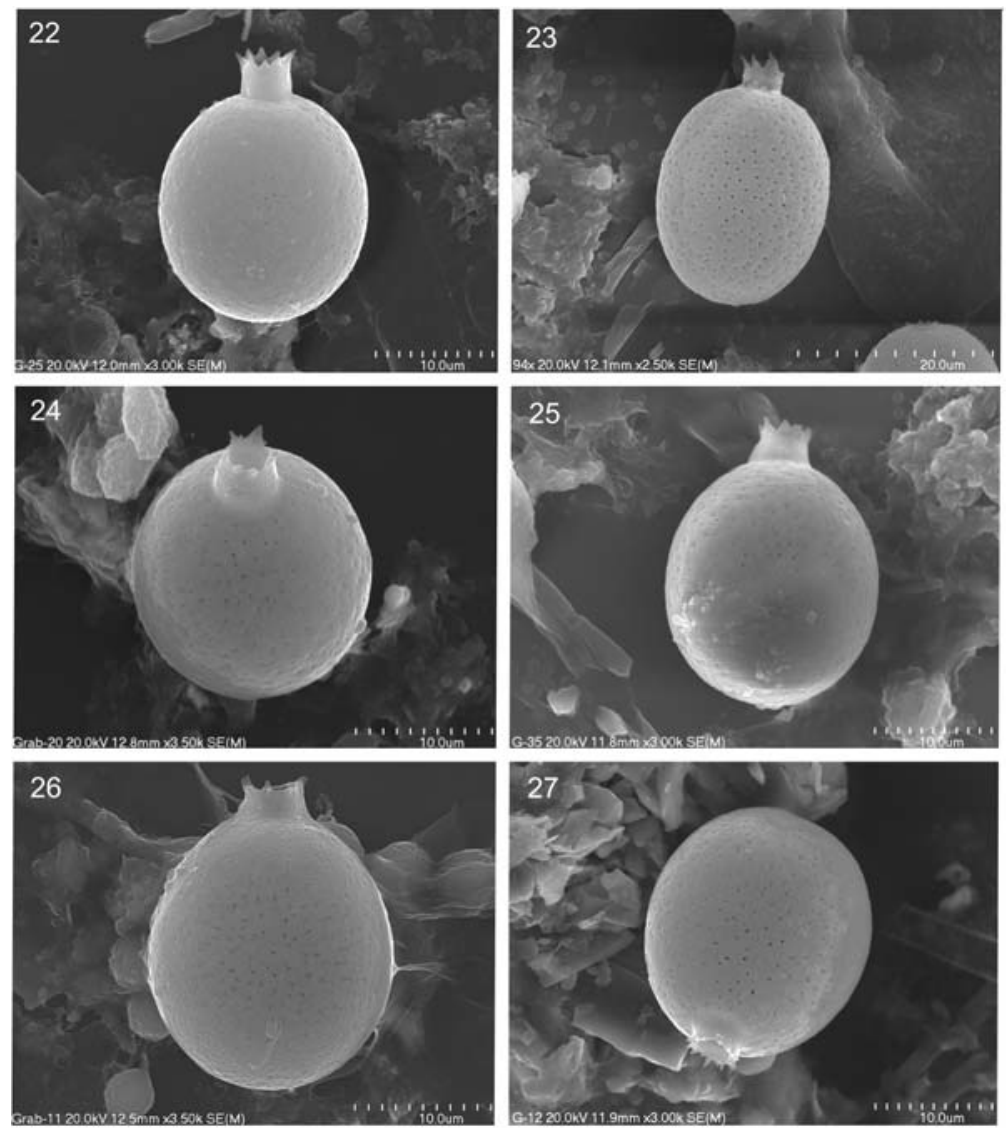

Figs 22-27: 22. T. planctonica var. planctonica fo. longicolli; 23. T. planctonica var. planctonica fo. oblonga; 24, 25. T. planctonica var.flexicollis; 26, 27. T. pavlovskoensis fo. pavlovskoense

\section{*T.planctonica var. flexicollis}

Balech 1944

Figs 24, 25

Lorica ellipsoid, punctate (ca. 2-3 points per $\left.1 \mu \mathrm{m}^{2}\right), 17.1-18.5 \mu \mathrm{m}$ wide, $21.0-22.5 \mu \mathrm{m}$ long; apical pore surrounded by well developed collar, narrowed and toothed at the rim; occurred frequently at sites 1 and 3. Reported from Europe, Asia, Africa and South America; uncommon. Note: similar to T. flexicollis Dreżepolski 1925, which has a collar with smooth rim, and to $T$. similis which has a more curved collar.

\section{T.pavlovskoensis (Poljanskij)} Popova 1951 fo. pavlovskoense

Figs 26, 27

Lorica broadly oblong, punctate (1-3 point per $\left.1 \mu \mathrm{m}^{2}\right), 18.0-19.0$ wide, $21-23.0 \mu \mathrm{m}$ long; apical pore surrounded by collar $2.5-2.8 \mu \mathrm{m}$ high with several spines at the rim; occurred frequently at site 2 . Repor- ted from Europe and Asia not common. Note: very similar to $T$. planctonica, can be mistakenly determined. Our specimens were smaller than those described by Popova (1951: 227, pl.4, figs 6-9).

\section{T. dubia Swirenko 1914 fo. dubia}

Fig. 53

Lorica cylindrical, smooth, ca.12.5 $\mu \mathrm{m}$ wide and $23 \mu \mathrm{m}$ long; apical pore surrounded by collar $3.0 \mu \mathrm{m}$ wide, $2.3 \mu \mathrm{m}$ high; occurred sparsely at site 2 .Widespread but not common.

\section{T.pseudobulla Swirenko 1914}

Fig. 54

Lorica ovoid, smooth, ca.13.8 $\mu \mathrm{m}$, wide and $25.5 \mu \mathrm{m}$ long; collar ca. $3 \mu \mathrm{m}$ high; occurred singly at site 2 . Reported from Europe, South and North America. Note: dimension of our specimen is smaller than described by Swirenko but the same as described from Argentina by Ballech (1944, p. 284: 24-25 $\mu \mathrm{m}$ long,). 

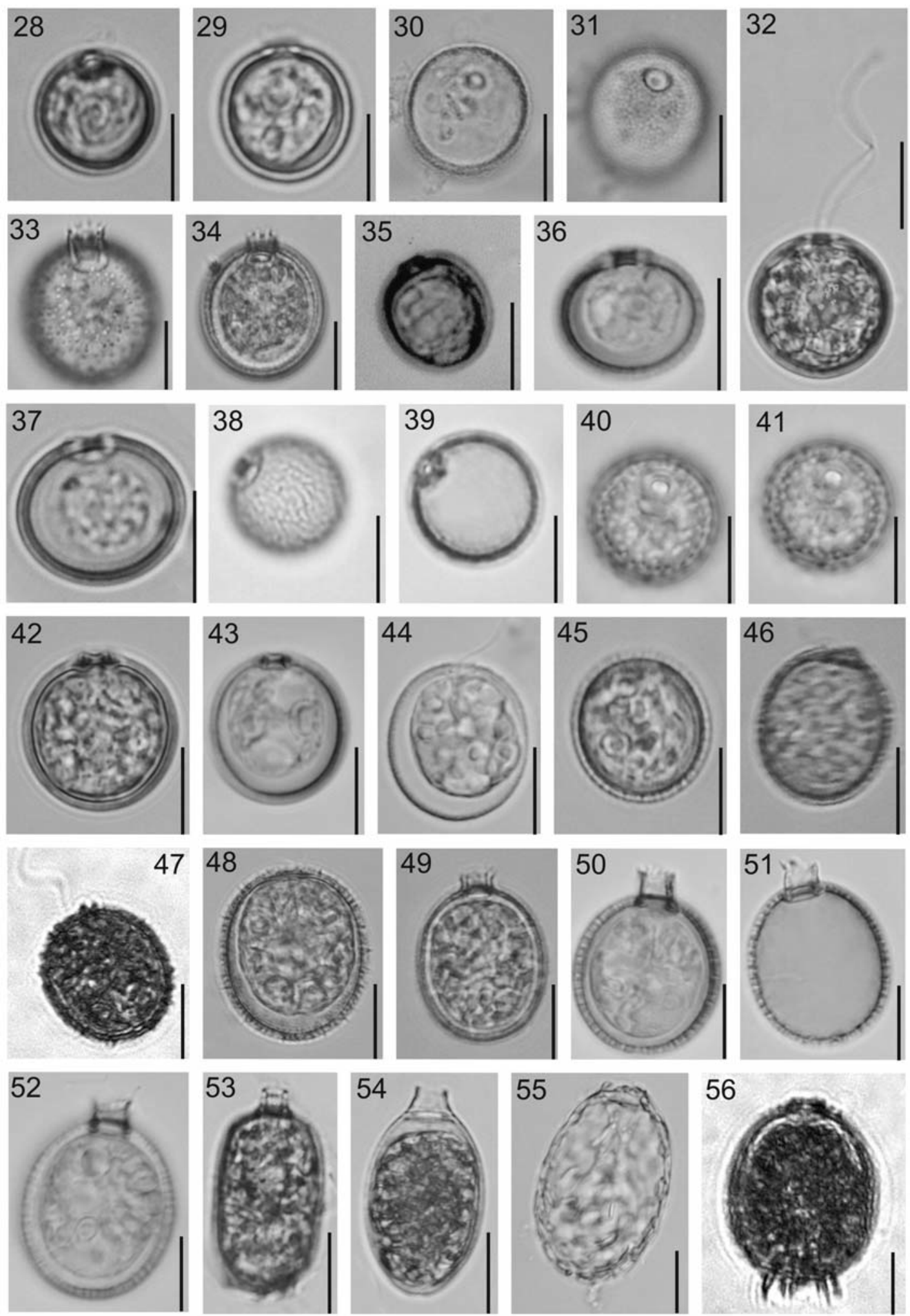


\section{*T. silvatica Swirenko 1914}

Fig. 55

Lorica, elliptic, slightly narrowed at the anterior end, irregularly scrobiculate, ca. $19.5 \mu \mathrm{m}$ wide and $30 \mu \mathrm{m}$ long; apical pore surrounded by thickening; occurred singly at site 2. Reported rare, from Asia and Europe. Note: similar to T. cactacea Playfair 1915 which is bigger than our specimen and has collar.

\section{T. armata (Ehrenberg) Stein 1878 var. armata Fig. 56}

Lorica broadly oval, covered by short spines at the anterior part, ca. $22.5 \mu \mathrm{m}$ wide and $30 \mu \mathrm{m}$ long, with 4-6 spines at the posterior end; apical pore surrounded by low collar; occurred sparsely at sites 2 and 3. Cosmopolitan, widespread.

\section{Summary}

Nine major taxonomic groups of algae occurred in the phytoplankton of Siemianowka Reservoir in 1994. Examples of Cyanoprokaryota, Bacillariophyceae, Chlorophyceae and Euglenophyta were always noted, with one group being dominant and the others co-dominant. Other five groups (Cryptophyta, Pyrrophyta, Chrysophyceae, Xanthophyceae, Zygnematophyceae) were noted occasionally. The Chlorophyceae showed the least change in biomass: Chlorella sp., Coelastrum microporum Näg., Dictyosphaerium pulchellum Wood var. pulchellum Wood, Scenedesmus spp. were the most common. Others were: Pediastrum boryanum (Turpin) Meneghini var. longicorne Reinsch, P. duplex Meyen var. gracillimum West et $\mathrm{G}$. S. West and $P$. biradiatum Meyen var. biradiatum (Figs 59-62). The highest Bacillariophyceae biomass $\left(\max 9.42 \mathrm{mg} \mathrm{dm}^{-3}\right.$ ) was noted from April to June. Dominants diatoms were Aulacoseira granulata (Ehr.) Simonsen, Stephanodiscus hantzschii Grunow (Figs 57, 58), S. neoastraea Hakannson \& Hickel, Cyclotella meneghiniana Kützing and $C$. planctonica Brunnthalter. In July a rapid increase occurred in the biomass of Euglenophyta and Cyanoprokaryota (Fig. 3). In the samples from summer phytoplankton (June-September), two phyla were co-dominant, Chlorophyceae and Bacillariophyceae.
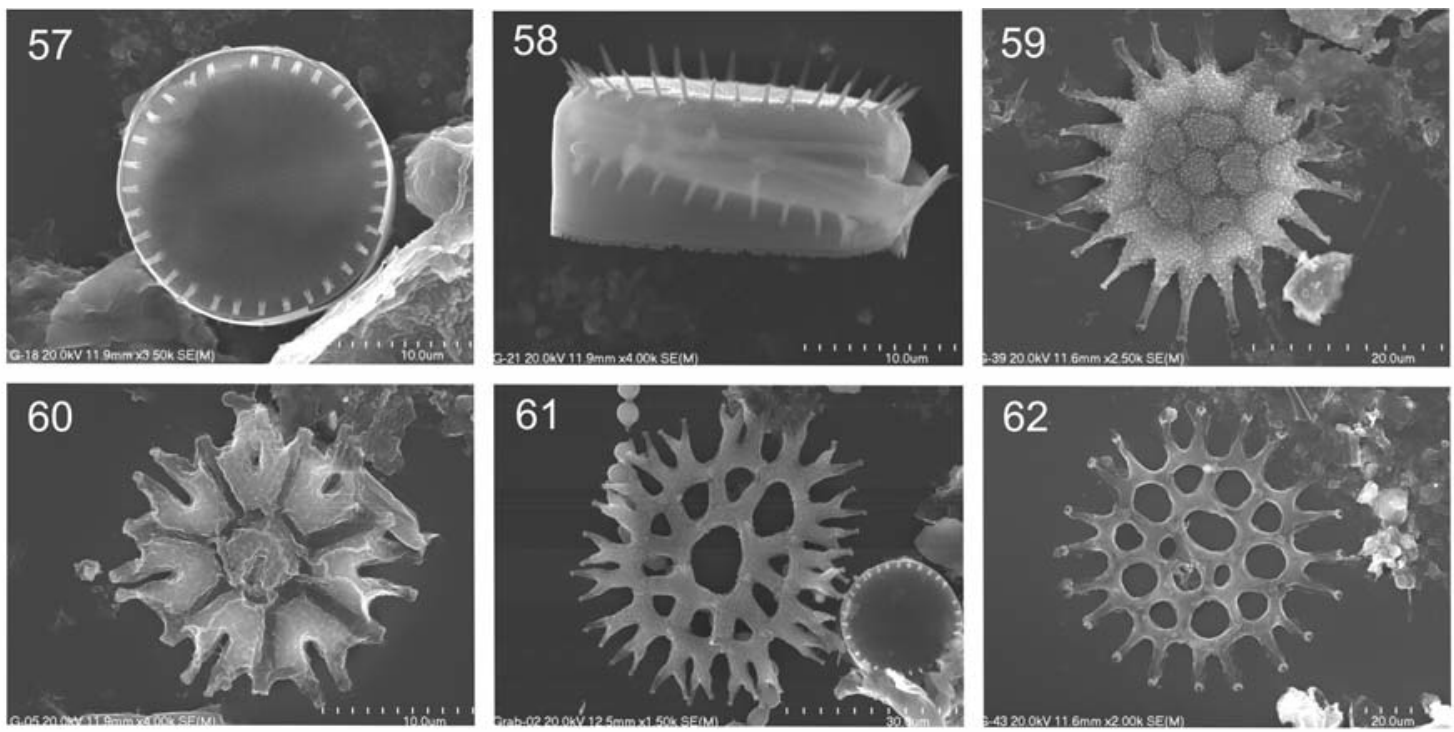

Figs 57-62: 57, 58. Stephanodiscus hantzschii; 59. Pediastrum boryanum var. longicorne; 60. Pediastrum Conf. tetras; 61. P. biradiatum var. biradiatum; 62. P. duplex var. gracillimum

Figs 28-56: 28, 29. T. volvocina var. volvocina; 30,31. T. volvocina var. punctata, the same specimen in various focus; $32 . T$. volvocinopsis var. volvocinopsis; 33, 34. T. volvocina var. coronata, the same specimen in various focus; 35 . T. oblonga var. australica; 36,37 . T. curta var. minima, the same specimen in various focus; 38,39 . T. rugulosa fo. Meandrina, the same specimen in various focus; 40, 41. T. compacta, the same specimen in various focus; 42. T. volvocinopsis var. volvocinopsis; 43, 44. T. oblonga var. oblonga; 45. T. intermedia fo. intermedia; 46. T. neotropica; 47. T. pseudofelix; 48. T. hispida var. hispida; 49. T. planctonica var. planctonica fo. planctonica; 50-52. T. planctonica fo. ornata; 53. T. dubia fo. dubia; 54. T. pseudobulla; 55. T. silvatica; 56. T. armata var. armata. 
The highest biomass of Euglenophyta occurred in July (av. $0.984 \mathrm{mg} \mathrm{dm}^{-3}, 21 \% \mathrm{~PB}$ ). In August the biomass of the Euglenophyta decreased as the biomass of Cyanoprokaryota increased (mainly Aphanizomenon flosaquae Ralfs ex Born. et Flah var. klebahnii Elenk).

The results of several year regional studies on euglenophytes in different moderately polluted water bodies all over the world show that the structure of euglenophytes communities is generally the same. Usually Trachelomonas, Euglena, Phacus, Lepocinclis and Monomorphina occurred in high numbers (eg. Safonova 1987, Holz et al. 1997, Dasí et al. 1997, Wołowski 1998, Naselli-Flores 2000, Paczuska et al. 2002).

According to Safonova (1987) euglenophytes generally represent $0-2 \%$ of the phytoplankton biomass. Holz et al. (1997) showed that the mean summer relative abundances of euglenophytes in the eutrophic Pawnee Reservoir (USA) was $4 \%$ of the phytoplankton abundances. For hard-water Spanish reservoirs, Dasí et al. (1998) described the maximum percentage of biomass of most representative summer euglenophyes (Trachelomonas sp., Euglena sp., Phacus longicauda) as $1-20 \%$. Usually the number of taxa is not higher than $6 \%$, and is located on the $4^{\text {th }}$ place among the other groups of algae. The study by Safonova (1987) showed that in clean lakes there were 5-18 taxa of euglenophytes - ca. 1.7-6\% among all the groups of taxa occurring in West Siberia. Her results confirm that euglenophytes are not a quantitatively significant component of algal communities in clean or moderately clean waters. The representants of Euglena species quickly react to the change of organic level pollution in water, e.g. Vetrova (1983) reported 93 taxa in sewage treatment ponds in a sugar factory, representing $32 \%$ of all the taxa. Many euglenophyte taxa included on the saprobes list are important organisms acting as indicators of pollution.

Among 40 taxa of euglenophytes found in SR during summer 1994, the most abundant were T. volvocina var. volvocina, $T$. volvocinopsis var. volvocinopsis, T. intermedia var. intermedia, T. hispida var. hispida and T. planctonica. This resembles Safonova's (1987) long-term observations from Russia. She concluded that Trachelomonas occurred abundantly among the euglenophyta groups in various types of West Siberia water bodies. Trachelomonas was also abundant in these lakes.

The present results are also similar to those reported by Conforti and Ruiz (2001) from Chunam Reservoir in South Korea. They recorded 96 euglenophyta taxa, and among them 9 belonged to the Euglena genus, 11 to Lepocinclis, 19 to Phacus, and 57 to Trachelomonas.

Our results confirm that loricate Euglenophyta are important components of euglenophyte communities occurring in reservoirs, even though the genus Strombomonas Defl. was not always observed.

Most of the taxa of euglenophytes recorded in the Siemianówka Reservoir are cosmopolitan and widespread, though nine taxa were recorded for the first time for Poland. T. curta var. minima described from Argentina by Tell and Zalocar (1985), also reported occasionally from Asia, USA and elsewhere in Europe, is probably cosmopolitan, but difficult for determine using LM. T. intermedia var. papillata, which appears to be cosmopolitan, is probably common in Poland, but had not previously been recognized. T. neotropica, described by Balech (1944) from Brazil, has been reported from Asia and Europe, but it is not common. T. globularis fo. punctata described by Skvortzov (1917) from Europe and Asia as comb. nova by Safonvoa (1966) is not common, probably cosmopolitan. T. oblonga var. australica, described by Playfair (1915) from Australia, has been reported from Europe, Asia and South America, but is not common. Because it is very similar to other varieties, such as truncata and attenuata, it can be mistakenly determined as T. volvocina var. derephora; T. planctonca fo. longicollis, T. planctonica fo. ornata, T. planctonica var. flexicollis. All varieties are probably common, but it is very difficult to determine all of them using only LM. T. silvatica was reported from Europe and Asia by Swirenko (1914) as rare.

\footnotetext{
Acknowledgements

The study was supported by the State Committee for Scientific Research (KBN) under projects number P04C 03621 and 661299102. We are grateful to Dr. Brian Whitton for comments and help with English. The authors would like to thank Professor Andrzej Górniak and Dr. Elżbieta Jekatierynczuk-Rudczyk for their assistance during fieldwork. We also thank Dr. Jolanta Piątek for help with generating plates.
}

\section{References}

Balech E. 1944. - Trachelomonas de la Argentina. Anales Mus. Argent. Ci. Nat. „Bernardino Rivadavia”, 41, 221-321.

Bozzola J.J \& Russell L.D. 1991. - Electron microscopy. Principles and techniques for biologists. Jones and Bartlett Publishers, Boston 542p.

Bucka H. \& Wilk-Woźniak E. 2000. - Monografia. Gatunki Kosmopolityczne i ubikwistyczne wśród glonów pro-i eukariotycznych wystęujacych $w$ zbiornikach wodnych Polski południowej. (A monograph of cosmopolitan and ubiquitous species among pro- and eukaryotic algae from water bodies in southern Poland). Zakład Biologii Wód, Kraków, 253p. 
Conforti V. 1993. - Study of the Euglenophyta from Camaleao lake (Manaus-Brazil). I Trachelomonas Ehr. Rev. Hydrobiol. Trop., 26, 3-18.

Conforti V. 1993a. - Study of the Euglenophyta from Camaleao lake (Manaus-Brazil). II Strombomonas Defl. Rev. Hydrobiol. Trop., 26, 187-193.

Conforti V. \&. Perez C.M. 2000. - Euglenophyceae of Negro River, Uruguay, South America. Arch. Hydrobiol. Suppl., 132, 59-78.

Conforti V. \& Ruiz L. 2001. - Euglenophyta from Chunam Reservoir (South Korea). II. Trachelomonas Ehr. Arch. Hydrobiol. Suppl., 138, 117-145.

Conrad W. \& Van Meel L. 1952. - Matériaux pour une monographie de Trachelomonas Ehrenberg 1834, Strombomonas Deflandre 1930 et Euglena Ehrenberg 1832, genres d'Euglénacées. Mém. Inst. Roy. Sci. Nat. Belg., 124, 1-176.

Da Cunha A.M. 1914. - Contribucao para o conhecimento da fauna de Protozoarios do Brazil. Mem. Inst. Oswaldo Cruz, 6, 169-179.

Dangeard P.A. 1901. - Recherches sur les Eugléniens. Le Botaniste, 8, 97-360.

Dasí M. J., Miracle M. R., Camacho A., Soria J. M. \& E. Vincente, 1998. - Summer phytoplankton assemblages across trophic gradients in hard-water reservoirs. Hydrobiologia, 369/370, 27-43.

Deflandre G. 1926. - Monographie du genre Trachelomonas Ehrenberg. Imprimerie André Lesot, Nemours 162.

Dreżepolski R. 1925. - Przyczynek do znajomości polskich Euglenin. Supplément à la connaissance des Eugléniens de la Pologne. Kosmos, 50, 173-270.

Fjerdingstad E. 1965. - Taxonomy and saprobic valency of benthic phyto-micro organisms. Int. Revue Ges. Hydrobiol., 50, 475-604.

Górniak A. \& Chocian G. 1999. - Seasonal and longitudinal variation of crustacean zooplankton in the Siemianówka Reservoir (NE Poland). Acta Hydrobiol., 41 (Suppl. 6), 231-241.

Górniak A. \& Grabowska M. 1996. - Limnology of the Siemianówka dam reservoir (eastern Poland). 3. Formation of phytoplankton communities in the first years after filling. Acta Hydrobiol., 38, 99-108.

Górniak A. \& Jekatierynczuk-Rudczyk E. 1995a. - Limnology of the Siemianówka dam reservoir (eastern Poland). 1. Environmental conditions. Acta Hydrobiol., 37, 1-9.

Górniak A. \& Jekatierynczuk-Rudczyk E. 1995b. - Limnology of the Siemianówka dam reservoir (eastern Poland). 2. Seasonal and horizontal differentiation of water chemistry. Acta Hydrobiol., $37,11-20$

Górniak A. \& Jekatierynczuk-Rudczyk E. 1998. - Water quality in the Siemianówka reservoir (NE Poland). Internat. Rev. Hydrobiol., 83, 311-318.

Górniak A., Wiśniewolski R. \& Kornijów R. 2000. - Koncepcja rekultywacji zbiornika Siemianówka, 23p.

Górniak A., Zieliński P., Jekatierynczuk-Rudczyk E., Grabowska M. \& Suchowolec T. 2002. - The role of dissolved organic carbon in the shallow lowland reservoir ecosystem. Acta Hydrochim. Hydrobiol., 30,179-189.

Grabowska M. 1998. - Blooms of Cyanophyta in Siemianówka dam reservoir in the first years after filling. Oceanol. Studies, 27, 27-31.

Grabowska M. 1999. - Phytoplankton assemblages in the eutrophic lowland Siemianówka Reservoir (NE Poland). Acta Hydrobiol., 41 (Suppl. 6),145-152.

Grabowska M. 2005. - Cyanobacteria blooms in polyhumic Siemianówka dam reservoir in 1992-2003. Oceanol. Hydrobiol. Studies, 34, 73-85.
Grabowska M., Górniak A., Jekatierynczuk-Rudczyk E. \& Zieliński P. 2003. - The influence of hydrology and water quality on phytoplankton community composition and biomass in a humoeutrophic reservoir Siemianówka reservoir (Poland). Ecohydrol. Hydrobiol., $3,185-196$

Holz J. C., Hoagland K. D., Spawn R. L., Popp A. \& Andersen J. L. 1997. - Phytoplankton community response to reservoir aging, 1968-92. Hydrobiologia, 346, 183-192.

Jurkiewicz-Karnkowska E. 1999. - Mollusc communities in a humic dam reservoir (Sieminówka, eastern Poland): diversity and abundance. Pol. J. Ecol., 47,307-322.

Kolkwitz R. \& Marsson M. 1908. - Ökologishe der pflanzlichen Saprobien. Ber. Deutsch. Bot. Ges., B 26a, 505-519.

Kusel-Feltzman E. 2002. - Die Euglenophytenflora des Neusiedler Sees. Abhandlungen der Zoologische-Botanischen Gesellschaft in Osterreich, 32, 1-115.

Lepistö L.\& Rosenström U. 1998. - The most typical phytoplankton taxa in four types of boreal lakes. Hydrobiologia, 369/370, 89-97.

Naselli-Flores L. 2000. - Phytoplankton assemblages in twenty-one Sicilian reservoirs: relationships between species composition and environmental factors. Hydrobiologia , 424, 1-11.

Paczuska B., Paczuski R. \& Krasicka-Korczyńska E. 2002. Zbiorniki śródpolne i śródleśne południowego skraju Wysoczyzny Świeckiej (pojezierze Krajeńskie). Mikroflora, makrofity i środowisko. (Midforest and field ponds of the southern edge of Wysoczyzna Świecka -The Krajeńskie Lakes - microflora, macrophytes and the environment) Wydawnictwo uczelniane, Akademii Techniczno-Rolniczej. Bydgoszcz, 91p.

Playfair G. J. 1915. - The genus Trachelomonas. Proc. Linn. Soc. New South Wales, 40, 1-41.

Popova T. G. 1951. - Euglenovyje (Euglenineae) evropejskogo Severa SSSR. Tr. Bot. Akad. Nauk SSSR, 7, 165-414.

Popova T. G. 1955. - Evglenovyje vodorosli. Opredelitel prenovodnych vodoroslej SSSR 7. Izdatel'stvo Nauka, Moskva, 267 p.

Popova T. G. 1966. - Evglenovyje vodorosli (Euglenophyta). Flora Spor. Rast. SSSR, Izd. Nauka, Leningrad, 8, 1-412.

Safonova T. A. 1963. - Novyje i intereasnyje formy roda Trachelomonas Her. iż Tomskoj oblasti. Bot. Mat. Otd. Spor. Rast. Bot. Inst. AN SSSR. 16

Safonava T. A. 1987. - Evglenovyje vodorosly Zapadnoj Sibiri. Izdate'lstvo Nauka, Novosybirsk, 192 p.

Skuja H. 1956. - Taxonomische und biologische Studien über das Phytoplankton schwedischer Bienengewässer. Nova Acta Regiae Soc. Sci. Upsal. Ser. Iv, 16(3), 228-250.

Sladeček V. \& Sladečkova A. 1996. - Atlas of aquatic organisms with respect to the water supply, surface waters and wastewater treatment plants. Česká vědeckotechnická vodohospodářrská společnost, Praha, 350p.

Smakulska J. \& Górniak A. 2004. - Morphological variation in Daphnia cucullata Sars with progressive eutrophication of polymictic lowland reservoir. Hydrobiologia, 526,119-127.

Stein F. von 1878. - Der Organismus der Infusionstiere. Der Organismus der Flagellaten. Abt. 3(1). Engelmann, Leipzig, 154p.

Swirenko D.O. 1914. - Zur Kenntnis der russischen Algenflora. I. Die Euglenaceen der Gattung Trachelomonas. Arch. Hydrobiol. Planktonk., 9, 630-647.

Tarczyńska M. \& Zalewski M. 2000. - Toksyczność zakwitów sinic w zbiornikach zaporowych w Polsce. Materiały, XVIII Zjazdu Hydrobiologów Polskich, Białystok, 270p. 
Tell G. \& Conforti V. 1986. - Euglenophyta pigmentadas de la Argentina. - Biblioth. Phycol. 75, J. Cramer, Berlin-Stuttgart, 301p.

Tell G. \& Zalocar P. 1985. - Euglenophyta pigmentadas de la provincia del Chaco (Argentina). Nova Hedwigia, 41, 353-391.

Vetrova Z. I. 1983. - Flora vodoroslej kontinentalnych vodoemov Ukrainskoj SSR. Evglenovye vodorosli. Vypusk 1, czast 2 (Flora algarum aquariorum continentalium RSS Ucrainicae. [Euglenophyta, Pars 1, Fasc. 1]. Izdatel'stvo Naukova Dumka, Kiiv, 407p.

Wiśniewolski W. 2002. - Zmiany w składzie ichtiofauny, jej biomasa oraz odłowy w wybranych zbiornikach zaporowych Polski. Arch. Pol. Fish., 10, 5-73 [in Polish].
Wołowski K. 1998. - Taxonomic and environmental studies on euglenophytes of the Krakow-Częstochowa Upland (Southern Poland). Fragm. Flor. Geobot. Suppl. 6: 3-192.

Wołowski K. 2002. - Phylum Euglenophyta. Pages 144-179 in The freshwater algal flora of the British Isles. John D.M Whitton B.A. $\&$ Brook A. J. (eds), Cambridge University Press, Cambridge.

Wołowski K. \& Hindák F. 2004. - Taxonomic and ultrastructure studies of Trachelomonas Ehrenberg emend. Deflandre (Euglenophyta) from Slovakia. - Nova Hedwigia, 78, 179-207.

Wołowski K. \& Hindák F. 2005. - Atlas of Euglenophytes. VEDA, Bratislava, 136

Yamagishi T. 1992. - Plankton algae in Taiwan (Formosa). Uchida Rokakuho, Tokyo 252p. 